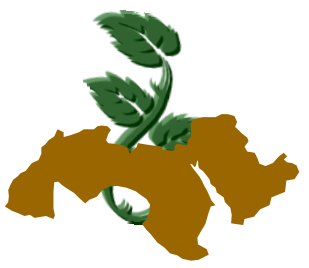

Arab Univ.

J. Agric. Sci., Ain Shams Univ., Cairo, 22(2), 431 - 437, 2014

\title{
THE EFFECT OF DIFFERENT TYPES AND RATES OF FERTILIZERS ON THE POPULATION DENSITY OF SAP SUCKING PESTS INHABITING COWPEA FIELDS
}

\author{
El-Khayat ${ }^{1}$, E.F.; Mona M. Ghallab ${ }^{2}$ and B.S. Wahba ${ }^{2}$ \\ 1- Department of Plant Protection Fac. of Agric., Benha Univ., Egypt \\ 2- Plant Protection Research Institute, A.R.C., Dokki, Egypt
}

Keywords: Bemisia tabaci, Coccus hesperidium, cowpea, fertilization treatments infestation levels, jassids, Thrips tabaci, Tetranychus. Urticae, $T$. cucurbitacearum

\section{ABSTRACT}

This study was carried out during 2012 and 2013 seasons in the Horticultural Research Station at Kanater El- Khairiya, Qualiobeya Governorate to throw light on the effect of different types and rates of fertilizer treatments on the rates of infestation of the cowpea plants, Vigna unguiculata L. by different pests Tetranychus urticae, T. cucurbitacearum (eggs and motile stages), Bemisia tabaci (eggs, nymphs, pupae \& adults), Thrips tabaci (nymphs \& adults) and green Jassids and on the resultant crop yield. Data revealed that treatment with NPK mixture recorded the highest infestation rate by $T$. urticae Koch, T.cucurbitacearum (Sayed) and $T$. tabaci in the two seasons, while the $\mathrm{K}_{2} \mathrm{O}$ fertilizer revealed the lowest infestation rates. Moreover, the $\mathrm{N}_{2}$ fertilizer recorded the highest infestation with whitefly and Jassids. The brown scale insects, Coccus hesperidium Linnaeus were firstly recorded in Egypt on cowpea plants but throughout the first season only.

The mixture treatments resulted highest yield (2428.3 \&2675 Kg./fed.) followed by Micro-element treatments $\left(1500 \& 1658.3 \mathrm{Kg}\right.$./fed.) then $\mathrm{K}_{2} \mathrm{O}$ fertilizer treatment $(1416.7$ \& $1553.3 \mathrm{Kg}$. /fed.) in 2012 and 2013, respectively; being significantly higher than control which recorded $(756.0$ \& $845.0 \mathrm{Kg}$. I fed.) for the two seasons.

However, the results showed a significant improvement in the uptake of NPK over the control, so it increased the production.

(Received 27 April, 2014)

(Accepted 16 June, 2014)

\section{INTRODUCTION}

Cowpea, Vigna unguiculata (L.) seeds contain high protein content $(20 \%$ to $40 \%)$ for human consumption, and cultivation of plants increases soil fertility. Cowpea may be also grown as a fodder crop of higher quality than cereals or forage grasses. (Akyeampong, 1986).

Cowpeas give back to the soil a huge supply of nitrogen, and can be used as a nitrogen fixer and as green manure. Seed are of high nutritional value as human diet, as well as a nutritious livestock food.

Fertilizers are sources of mineral elements which plants require for growth and development. Essential mineral elements are found ammonium sulfate, potassium sulfate, super phosphate, mixture of NPK and Microelements which are of great values in plant growth and development; their deficiencies or excesses result in marked effects on growth and crop yield.

Nymphs and adult of Thrips tabaci are not less in their seriousness than spider mite; also Bemisia tabaci is highly polyphagous pest, infesting more than 600 plant species including a many varieties of vegetable and ornamental plants (Secker et al. 1998); its damage is caused directly by feeding on phloem or deposition of honeydew, or indirectly by physiological disorders and transmission of more than 150 plant viruses (Oliveira et al 2001).

The objective of this study was to investigate the effectiveness of different fertilizer treatments on the rate of pests' infestation to cowpea plants and their effects on the resultant yield.

\section{MATERIAL AND METHODS}

A randomized complete block design was used to perform this experiment for studying the effect of 
different types of fertilizers: ammonium, phosphorus and potassium on the rate of infestation with 5 piercing and sucking pests of (Baladi) cowpea variety and on the yield. The experimental area was about $\left(118 \mathrm{~m}^{2}\right)$ divided into 18 plots of $4.2 \mathrm{~m}^{2}$ each for the five different fertilizers and the control; 3 replicates for each treatment. Each plot consists of 2 ridges of 3 meters long and $60 \mathrm{~cm}$ apart. The seed were sowed on April $1^{\text {st }}$ in both years at 25 $\mathrm{cm}$ spacing between hills. The tested fertilizers were used as follow:

1- Ammonium sulfate, $20.6 \% \mathrm{~N}_{2}$ at a rate of 100 $\mathrm{kg} / \mathrm{feddan}$.

2- Calcium super phosphate, $15.5 \% \quad \mathrm{P}_{2} \mathrm{O}_{3}(200$ $\mathrm{kg} / \mathrm{feddan}$ ).

3- Potassium sulfate, $48 \% \mathrm{~K}_{2} \mathrm{O}$ (100 kg/feddan).

4- A mixture of the 3 previous fertilizers $N, P$ \& $K$ at the rate of 100,200 and $100 \mathrm{~kg} / \mathrm{feddan}$, respectively.

5- Micro-elements solved in water as Folifert [ $\mathrm{Zn}$ $7.06 \%$; Mn $4.20 \%$; Fe $2.80 \%$; Cu $2.0 \%$; Bo $0.60 \%$ \& Mo (Molibidium) $0.05 \%$ ].

6- The control plots (without any treatments).

Two sprays were applied using plastic atomizer, the first after complete germination and the second spray was on leaves at the time of flowering. The control plots were treated with water in the same days of spraying foliage fertilizers while the remaining fertilizers were added to soil around the plants in the time of spraying foliage fertilizers. Precautions had been done to prevent contamination among fertilizer treatments. All plots received the normally recommended agricultural practices and kept free from any insecticidal treatment. When the dry pods of cowpea reached the time of harvest, those were picked up and weighed.

\section{Sampling technique}

Sampling started 24 days after sowing and continued for 11 successive weeks until harvest in the two years $2012 \& 2013$. Adults of B. tabaci were counted on the undersides of leaves of 10 plants/replicate in the morning before sunrise. Samples of 10 leaflets from each replicate were randomly picked from three levels of plants, kept in tightly closed paper bags and transferred to the laboratory where the observed pests were counted by the aid of a binocular stereomicroscope. The total individuals of $T$. urticae, $T$. cucurbitacearum (eggs and moving stages), B. tabacci (eggs, nymph and pupal stages) and T. tabaci (nymphs and adults) were counted as total numbers on the upper and lower surfaces of the leaflet.

\section{Laboratory studies}

\section{a- Estimation of cowpea leaves components}

The phytochemical components of cowpea leaves for (Baladi) variety were estimated to determine the correlation between the plant components and the rate of infestation by white fly $\mathrm{Be}$ misia tabaci in the different types of fertilizer treatments under field conditions in 2012 and 2013 seasons.

Leaves of each sample were cleaned and washed with distilled water, then quickly dried by placing them gently between filter papers to remove the excess of water. The fresh weight of leaves was recorded. The leaves were placed in dry oven at $60^{\circ} \mathrm{C}$ for one day. The dry powder of leaves was kept in glass bottles to determine, total protein, the percentages of total reduced and non reduced sugars according to A.O.A.C. (1995).

\section{Statistical analysis}

Statistical analysis for ANOVA was carried out by using SAS 9.3.1 Portable. Whereas the means were compared through LSD tests, least significant differences at $P=0.05$ level.

\section{RESULTS AND DISCUSSION}

\section{a- Spider mite, Tetranychus urticae Koch}

As shown in Tables (1\&2), the lowest mean counts of $T$. urticae, eggs were recorded in cowpea plants received $\mathrm{N}_{2}$, being 0.38 \& 0.66 eggs/leaflet in 2012 and 2013 cowpea seasons. On contrary, the NPK mixture led plants to attract $T$. urticae females which laid more eggs on leaves than the untreated plants and the other remaining treatments 2.64 \& 1.81 eggs / leaflet in the two seasons respectively with significant differences comparing to the remaining treatments, followed by Micro-elements, phosphorus then potassium. The mean numbers of the moving stage have the same trend of increase or decrease as the egg infestation.

In accordance with such results, El-Halawany et al (1989) mentioned that population of $T$. urticae increased as potassium and phosphorus concentration increased; also, they recorded that the number of eggs and mites' population were less in untreated cowpea plants as compared to fertilizer treated plots. 
Table 1. The effect of different fertilizers on the infestation of cowpea plants by some piercing sucking pests and on the resultant yield during 2012 season

\begin{tabular}{|c|cc|cc|cccc|}
\hline \multirow{2}{*}{ Treatments } & \multicolumn{2}{|c|}{ T. urticae } & \multicolumn{2}{c|}{ T. cucurbitacearum } & \multicolumn{4}{c|}{ Bemisia tabaci } \\
\cline { 2 - 9 } & Eggs & Mot. & Eggs & Mot. & Eggs & Nymphs & Pupae & Adults \\
\hline Control & 1.58 & 1.51 & 1.45 & 0.14 & 0.17 & 0.27 & 0.03 & 1.31 \\
N & 0.38 & 0.39 & 0.31 & 0.02 & 0.31 & 0.45 & 0.05 & 5.62 \\
P & 2.06 & 1.33 & 1.6 & 0.18 & 0.22 & 0.27 & 0.01 & 1.10 \\
K & 1.94 & 1.75 & 1.72 & 0.16 & 0.30 & 0.38 & 0.04 & 3.14 \\
Mix. (NPK) & 2.64 & 2.78 & 2.02 & 0.22 & 0.30 & 0.31 & 0.02 & 1.91 \\
Microelements. & 1.96 & 1.56 & 1.49 & 0.19 & 0.18 & 0.30 & 0.02 & 2.70 \\
\hline LSD at 5\% & 1.26 & 1.28 & 0.83 & 0.96 & 0.1 & 0.11 & 0.03 & 1.51 \\
\hline
\end{tabular}

\begin{tabular}{|c|c|c|c|c|}
\hline Treatments & $\begin{array}{c}\text { Thrips tabaci } \\
\text { Adults \& nymphs }\end{array}$ & Jassid & Brown scale insect & Yield \\
\hline Control & 0.61 & 0.79 & 0.12 & 756.0 \\
N & 0.62 & 1.35 & 0.24 & 1213.3 \\
P & 0.69 & 1.17 & 0.12 & 1416.7 \\
K & 0.31 & 0.84 & 0.57 & 1035.0 \\
Mix. (NPK) & 0.80 & 0.44 & 0.81 & 2428.3 \\
Microelements & 0.65 & 0.63 & 0.37 & 1500.0 \\
\hline LSD at 5\% & 0.21 & 0.21 & 0.21 & 377.56 \\
\hline
\end{tabular}

Table 2. Effect of fertilizers on population of four sap sucking pests infesting cowpea plants during 2013 season

\begin{tabular}{|c|cc|cc|cccc|}
\hline \multirow{2}{*}{ Treatments } & \multicolumn{2}{|c|}{ T. urticae } & \multicolumn{2}{|c|}{ T. cucurbitacearum } & \multicolumn{4}{c|}{ Bemisia tabaci } \\
\cline { 2 - 9 } & Eggs & Mot. & Eggs & Mot. & Eggs & Nymphs & Pupae & Adults \\
\hline Control & 0.63 & 0.66 & 1.09 & 0.05 & 0.77 & 0.48 & 0.02 & 0.17 \\
N & 0.66 & 0.35 & 0.79 & 0.05 & 0.84 & 0.51 & 0.05 & 0.47 \\
P & 0.88 & 0.52 & 1.32 & 0.07 & 0.63 & 0.50 & 0.01 & 0.37 \\
K & 0.79 & 0.55 & 1.10 & 0.07 & 0.72 & 0.45 & 0.04 & 0.35 \\
Mix. (NPK) & 1.81 & 1.21 & 2.83 & 0.17 & 0.74 & 0.39 & 0.02 & 0.25 \\
Micro-elements & 1.10 & 0.70 & 1.52 & 0.09 & 0.47 & 0.27 & 0.02 & 0.33 \\
\hline LSD at 5\% & 0.75 & 0.50 & 0.80 & 0.05 & 0.21 & 0.14 & 0.03 & 0.30 \\
\hline
\end{tabular}

\begin{tabular}{|c|c|c|c|c|}
\hline Treatments & $\begin{array}{c}\text { Thrips tabaci } \\
\text { Adults \& nymphs }\end{array}$ & Jassid & Brown scale insect & Yield \\
\hline Control & 0.14 & 0.18 & Not registred in the & 845.0 \\
N & 0.15 & 0.35 & $2^{\text {nd }}$ season & 1346.67 \\
P & 0.13 & 0.23 & & 1553.3 \\
K & 0.11 & 0.30 & & 1128.3 \\
Mix. (NPK) & 0.15 & 0.31 & & 2675.0 \\
Microelements & 0.09 & 0.27 & & 1658.3 \\
\hline LSD at 5\% & 0.06 & 0.11 & & 413.09 \\
\hline
\end{tabular}




\section{b- Tetranychus cucurbitacearum (Sayed)}

The highest number of $T$. cucurbitacearum, (eggs and mobile stages) was observed on plants received NPK mixture $(2.02 \& 2.83$ eggs and 0.22 \& 0.17 individual /leaflet in the two seasons, respectively. While, treatment of plants by $\mathrm{N}_{2}$ was correlated with the lowest infestation by tetranychid eggs and mobiles stages in the two seasons $(0.31$ \& 0.79 eggs and 0.02 \& 0.05 individuals/leaflet, respectively) indicating significant by lower infestation rates compared to NPK mixture treatment.

Rather and Lavdari (2006) proved in their study that combination treatment of NP carried high mite population on the cowpea plants than potassium treated plots, and there was a direct relationship between fertilizer application to the population of Tetranychus turkestani on cowpea.

\section{c- White fly, Bemisia tabaci (Gennadius)}

The numbers of $B$. tabaci stages were influenced by application of fertilizer treatments. The highest mean seasonal counts were $(0.31$ and $0.84 \mathrm{egg}$ /leaflet) for plants treated with $\mathrm{N}_{2}$ followed by NPK mixture ( $0.30 \& 0.74$ egg/leaflet). Theses valus were significant by higher compared to control ( $0.17 \& 0.77$ eggs/leaflet) in the two seasons, respectively. On the other hand, the lowest mean population of $B$. tabaci eggs was recorded on plants treated with Micro-elements, demonstrated 0.18 \&0.47eggs/leaflet in the two seasons, respectively, being significantly lower compared to $\mathrm{N}_{2}$ treatment.

It could be observed from the same tables that infestation by nymphal stage took the same trend of infestations by eggs; i.e., the $\mathrm{N}_{2}$ treatment contributed the highest population of $B$. tabaci nymphs with mean counts $(0.45 \& 0.51$ nymphs /leaflet) in the two years, respectively, while $\mathrm{P}_{2} \mathrm{O}_{3}$ treatment revealed the lowest population with means $(0.27$ nymph/leaflet) in the first season and Microelements in the second season 0.27 nymph /leaflet.

Statistical analysis of data indicated significant differences between the $\mathrm{N}_{2}$ treatment and the other different fertilizers in the first season, while non significant differences occurred between treatments in the second season except for Microelements which showed significant by lower infestation rates than the control.

The pupal stage of whiteflies were affected by the different fertilizers; the lowest means of pupae occurred in plots received the $\mathrm{P}_{2} \mathrm{O}_{3}$ fertilizer (0.01pupa/leaflet) in the two seasons, without significant difference between treatments except for $\mathrm{N}_{2}$ compared to control. On the other hand, the $\mathrm{N}_{2}$ treatment recorded the highest infestation by whitefly pupae ( 0.05 pupa/leaflet) in the two seasons with significant difference compared to $\mathrm{P}_{2} \mathrm{O}_{3}$ treatment.

According to the adult stages counts, in the first season, plants treated with $\mathrm{N}_{2}$ showed the highest infestation rate by whitefly adults (5.62 individuals/ plant) with highly significant difference compared to control (1.31 adult / plant), while the $\mathrm{P}_{2} \mathrm{O}_{3}$ fertilizer showed the lowest incidence of whitefly adults' population with means 1.10 individuals/ plant with insignificant difference compared to control and significant difference compared to $\mathrm{N}_{2}$ fertilizer. In the second season, the adult stages of whitefly recorded insignificant differences between different fertilizers treatments.

The present results go in line with the finding of Simmons and Abd-Rabou (2008); they proved that egg, nymph, and adult whitefly counts were generally elevated with increased rates of ammonium sulfate.

\section{d- Thrips tabaci Lindquist}

The highest mean counts of $T$. tabaci on leaves of cowpea were recorded in plants treated with NPK (0.80 \& 0.15 individual/leaflet) in the two seasons, respectively, while the lowest count was recorded in plants treated with $\mathrm{K}_{2} \mathrm{O}$ fertilizer $(0.31$ individual/ leaflet) in the first season and Microelements (0.09 individuals/ leaflet) in the second seasons.

According to L.S.D values, T. tabaci counts were significantly higher the NPK mixture treatments than $\mathrm{K}_{2} \mathrm{O}$ fertilizer.

The obtained results agree with the finding of Jeyaraman and Balasubramanian (1988) in their study about the role of Potassium in reducing the number of thrips from 1.54 thrips/leaf in untreated plants to 1.30 thrips/leaf after potassium application. Also, Ebaid and Mansour (2006) mentioned that Microelements ( $\mathrm{Zn}, \mathrm{Mn}, \mathrm{Fe}$ and $\mathrm{Cu}$ ) had significant effect in reducing thrips population on cotton plants.

\section{e- Jassid, Empoasca decipiens Paoli}

The $\mathrm{N}_{2}$ fertilizer treatment showed the highest infestation rate than the other fertilizer treatments with mean numbers $1.35 \& 0.35$ individuals / leaflet, in the two seasons, respectively. While NPK 
and $\mathrm{P}_{2} \mathrm{O}_{3}$ treatment revealed the lowest infestations by Jassid being $0.44 \& 0.23$ individuals / leaflet, in the first and second seasons, respectively indicating significant difference in the first season and non significant difference in the second seasons compared to control (0.79 \&0.18 individual / leaflet) in the two seasons, respectively.

The observation of Habibullah et al (2007) indicated that an excessive dose of $\mathrm{N}_{2}$ fertilizer produced lush green plants which attract the sucking pests such as jassids and whiteflies, so, their populations per leaf were higher in plants treated with high dose of $\mathrm{N}_{2}(200 \mathrm{~kg})$ compared to those treated with few dose $(100 \mathrm{~kg})$.

\section{f- Brown scale insect, Coccus hesperidium Linnaeus}

It could be noticed that Cowpea plants which were treated with NPK, suffered the highest infestation rate by the Brown scale insect than all the remaining treatments with mean count 0.81 individuals/leaflet followed by $\mathrm{K}_{2} \mathrm{O}$ and Micro-elements fertilizers $0.57 \& 0.37$ individuals/leaflet, respectively. On the other hand the $\mathrm{P}_{2} \mathrm{O}_{3}$ fertilizer revealed the lowest infestation. According to L.S.D values, there were significant difference between (NPK) treatment compared to control ( 0.12 individuals/leaflet), while insignificant differences were found between the other treatments except for $\mathrm{K}_{2}$ O fertilizer.

\section{Relationship between fertilizer treatments and resultant yield}

Data presented in Tables (1 \& 2) show cowpea, Baladi variety that received different rates of the mixture treatment (NPK) had the largest weight of dry pods yield during 2012 and 2013 seasons recorded (2428.3\& $2675.0 \mathrm{Kg} /$ fed., respectively). On contrary, $\mathrm{K}_{2} \mathrm{O}$ treatment and untreated plants had the lowest weight of dry pods' yield 1035.0 \& $1128.3 \mathrm{Kg} / \mathrm{fed}$.) and $(756.0 \& 845.0 \mathrm{Kg} / \mathrm{fed}$.), in the two seasons, respectively. Statistical analysis demonstrated that means of dry pods weight after NPK fertilizer treatment was significantly higher than other fertilizers. Despite the fact that pest infestation on NPK treated plots was higher, it did not cause any significant effect on the yield, this was due to the phenomena of tolerance; this result was previously indicated by Huber 1989.

\section{Estimation of cowpea leaf components}

Data in Table (3) indicated that the percentages of total protein contents in cowpea plant leaves were higher in the plants treated with NPK fertilizer in the two seasons, being 27.47 and 17.44 $\%$, respectively, showing significant differences compared with untreated plants (23.03 \& 13.75\%), respectively. This finding is in accordance with the results obtained by Marschner (1995) who proved that an excess of $\mathrm{N}$ can lead to higher accumulation of amino acids which, in turn, can increase attack rates of sap sucking insects such as Aleurothrixus aepim Goeldi (Homoptera : Aleyrodidae) in cassava plants. Moreover, Osman et al (1992) proved that the presence of micro-nutrients $(\mathrm{Zn}$, $\mathrm{Mn} \& \mathrm{fe}$ ) treatments, significantly, increased the yield of protein in leaves and the application of $\mathrm{P}_{2} \mathrm{O}_{3}$ decreased the total protein. These results were in conformity with the present observations, so, the uptake of Micro-element fertilizers increases the total protein in leaves which was found to be $25.07 \%$ being more than the control $23.03 \%$, while the application of $\mathrm{P}_{2} \mathrm{O}_{3}$ decreased the total protein in leaves $(21.79 \%)$ compared to control.

Meanwhile, the lowest percentage of total sugar contents were found in plants treated with phosphorus fertilizer in the two seasons, recorded 2.43 and $8.17 \%$, respectively being significantly higher compared to control $3.72 \& 8.25 \%$, respectively, while non significant differences occurred between other treatments in the two seasons.

This investigation may explain field observations that cowpea plants were infested at different rates with different piercing sucking pests.

In conclusion, cowpea leaves of low nitrogen and phosphate contents were unsuitable for piercing sap sucking pests feeding and population increase. The late application of fertilizers and higher doses induced the attack by sap sucking pests to plants; therefore, optimum dose of fertilizers should be applied at proper time. 
Table 3. Chemical analysis of cowpea leaves induced by different type of fertilizers during 2012 \& 2013

\begin{tabular}{|c|cccc|cccc|}
\hline \multirow{2}{*}{ Treatments } & \multicolumn{4}{|c|}{2012} & \multicolumn{4}{c|}{2013} \\
\cline { 2 - 9 } & $\begin{array}{c}\text { Total } \\
\text { protein } \\
\%\end{array}$ & $\begin{array}{c}\text { Total } \\
\text { sugar } \\
\%\end{array}$ & $\begin{array}{c}\text { Reduced } \\
\text { sugar } \\
\%\end{array}$ & $\begin{array}{c}\text { Non } \\
\text { reduced } \\
\text { sugar } \%\end{array}$ & $\begin{array}{c}\text { Total } \\
\text { protein } \\
\%\end{array}$ & $\begin{array}{c}\text { Total } \\
\text { sugar } \\
\%\end{array}$ & $\begin{array}{c}\text { Reduced } \\
\text { sugar } \\
\%\end{array}$ & $\begin{array}{c}\text { Non } \\
\text { reduced } \\
\text { sugar } \%\end{array}$ \\
\hline Control & 23.03 & 3.72 & 2.95 & 0.78 & 13.75 & 8.25 & 4.19 & 4.07 \\
N & 26.6 & 3.64 & 2.38 & 0.86 & 16.37 & 8.3 & 4.22 & 4.08 \\
P & 21.79 & 2.43 & 1.61 & 0.82 & 13.31 & 8.17 & 4.23 & 3.94 \\
K & 23.54 & 2.99 & 2.35 & 0.64 & 13.87 & 8.18 & 4.16 & 4.02 \\
NPK & 27.47 & 3.24 & 2.88 & 0.77 & 17.44 & 8.27 & 4.2 & 4.07 \\
Microelements & 25.07 & 3.26 & 2.65 & 0.61 & 13.30 & 8.22 & 4.18 & 4.05 \\
\hline LSD & 4.13 & 0.84 & 0.75 & 0.13 & 1.78 & 0.02 & 0.02 & 0.02 \\
\hline
\end{tabular}

\section{REFERENCES}

Akyeampong, E. 1986. Potentials of forage legumes in farming systems of Sus-Saharan Africa. - Some responses of cowpea to drought stress; Proceedings of workshop held at ILCA, P.O. Box 5689, Addis Ababa, Ethiopia 16- 19 Sept. 1985 . Internat. Livestock Center for Africa. pp. 140- 159.

A.O.A.C. 1995. Methods of Analysis of the "Association of Official Analytical Chemists" $16^{\text {th }}$. Ed., Washington, D.C., 226 p.

Ebaid, G.H. and E.S. Mansour 2006. Relative population abundances of sap-sucking pests and associated predators in relation to nonchemical treatments in cotton fields in Egypt. Egypt. J. Biol. Pest control, 16(1\&2): 11-16.

El-Halawany, M.E., R.G. Abou-El-Ela, A.F. ElSherif and H.M. Ismail 1989. Effect of Microand Macro-nutrients in apple and apricot leaves on biology of Tetranychus arabicus and abundance of phytophagous mites. Egypt. J. Agric. Res. Rev. 67(1): 63 - 67.

Habibullah, S.A., Sabir, Shahzad and Ch.A. Mushtaq 2007. Effect of different doses of Nitrogen fertilizer on sucking insect pests of cotton Gossypium hirsutum. J. Agri. Res., 45(1): 43-48.

Huber, D.M. 1989. The roles of nutrition in the take all disease of wheat and other small grains in soil borne plant Pathogens Management of diseases with macro- and micro-elements. The American Psychopathological Society, St. Paul Minnesota, USA, APS: 46 - 75.
Jeyaraman, S. and R. Balasubramanian 1988. Role of Potassium treatment on yield and incidence of pests and disease in Cilli. Journal of Potassium, (2): 67 - 70.

Marschner, H. 1995. Mineral nutrition of higher plants. London: Academic Press, 1995.

Oliveira, M.R.V., T.J. Henneberry., P. Anderson 2001. History, current status, and olivera collaborative research projects for Bemisia tabaci. Crop Prot. 20: 709-723.

Osman, A.O., M.A. Eskarous and W.E. Ahmed 1992. The interaction of some micronutrients and Rhizobia on faba bean yield grown on sandy soil. Egypt. J. Agric. Res. Rev., 70(3): $693-701$.

Rather, A.Q. and A.Q. Lavdari 2006. Effect of soil fertilization on population build up of spider mite Tetranychus turkestani Ugarov \& Nikolskii in cowpea. Appl. Biol. Res., 8(1\&2): 47 - 50.

Secker, A.E., I.A. Bedford, P.G. Markham and M. E.C. William 1998. Squash, a reliable field indicator for the presence of B biotype of tobacco whitefly, Bemisia tabaci In Brighton Crop Protection Conference Conference-Pest and Diseases. British Crop Protection Council. pp. 837-842.

Simmons, A.M. and Sh. Abd-Rabou 2008. Population of the sweetpotato whitefly in response to different rates of three sulfurcontaining fertilizers on ten vegetable crops. vol. 15(1): 57 - 70 . 